\title{
Empirical Differences in Crime Categories by White-Collar Criminals
}

\author{
Petter Gottschalk \\ 1Department of Leadership and Organizational Management, BI Norwegian Business School, \\ Nydalsveien 37, Oslo 0484, Norway \\ Phone: + 4746410716 \\ Email address: petter.gottschalk@bi.no
}

\begin{abstract}
White-collar crime is financial crime committed by persons of respectability and social status. The purpose of this paper is to present empirical results from a study of convicted white-collar criminals in Norway. A national sample of 323 criminals was collected based on media coverage from 2009 to 2012. Crime was classified into the main categories of fraud, theft, manipulation, and corruption. Most criminals were convicted of fraud. They also received the longest jail sentence on average.
\end{abstract}

Keywords: white-collar crime; empirical study; fraud; theft; manipulation; corruption

\section{INTRODUCTION}

White-collar crime is financial crime committed by trusted and potentially reliable persons in important business positions. Sutherland (1949) in his seminal work defined white-collar crime as crime committed by a person of respectability and high social status in the course of his occupation. Research on white-collar crime is often based on anecdotal evidence, where famous white-collar criminals serve as examples for case studies (Simpson, 2011). While being relevant and interesting cases, the extent of generalization from such studies is questionable. What is needed is a larger sample of white-collar criminals that can be studied in terms of average values as well as variation in criminal characteristics (Gottschalk and Glasø, 2013).

With this larger sample, we can then study white-collar convicts using statistical techniques to identify and study groups of white-collar criminals. Therefore, this article is based on an empirical sample of 323 white-collar criminals in Norway, convicted in the period from 2009 to 2012. This article is focused on crime categories by white-collar criminals, since we find a great variety of criminal activities that are classified as financial crime. The article is concerned with the following research questions: What crime categories are most frequent within white-collar crime, what criminal characteristics can be found for white-collar criminals in each category, and what were the sentences in each category? 


\section{WHITE-COLLAR CRIMINALS}

According to Brightman (2009), Sutherland's theory of white-collar crime from 1939 was controversial, particularly since many of the academicians in the audience perceived themselves to be members of the upper echelon of American society, where white-collar criminals can be found. Despite his critics, Sutherland's theory of white-collar criminality served as the catalyst for an area of research that continues today. In particular, differential association theory proposes that a person associating with individuals who have deviant or unlawful mores, values, and norms learns criminal behavior. Certain characteristics play a key role in placing individuals in a position to behave unlawfully, including the proposition that criminal behavior is learned through interaction with other persons in the upper echelon, as well as interaction occurring in small intimate groups (Hansen, 2009).

In contrast to Sutherland, Brightman (2009) differs slightly regarding the definition of white-collar crime. While societal status may still determine access to wealth and property, he argues that the term white-collar crime should be broader in scope and include virtually any non-violent act committed for financial gain, regardless of one's social status. For example, access to technology, such as personal computers and the Internet, now allows individuals from all social classes to buy and sell stocks or engage in similar activities that were once the bastion of the financial elite.

In Sutherland's definition of white-collar crime, a white-collar criminal is a person of respectability and high social status who commits crime in the course of his occupation. This excludes many crimes of the upper class, e.g., most of their cases of murder, adultery, and intoxication, since these are not customarily a part of their white-collar crime activities (Benson and Simpson, 2009). It also excludes lower class criminals committing financial crime, as pointed out by Brightman (2009).

What Sutherland meant by respectable and high social status individuals are not quite clear, but in today's business world we can assume he refers to business managers and executives. They are, for the most part, individuals with power and influence that are associated with respectability and high social status. Part of the standard view of white-collar offenders is that they are mainstream, law-abiding individuals. They are assumed to be irregular offenders, not people who engage in crime on a regular basis (Benson and Simpson, 2009: 39):

Unlike the run-of-the-mill common street criminal who usually has had repeated contacts with the criminal justice system, white-collar offenders are thought not to have prior criminal records.

White-collar criminals are not entrenched in criminal lifestyles as common street criminals. Some of them belong to the elite in society, and they are typically individuals employed by and in legitimate organizations. What Podgor (2007) found to be the most interesting aspect of Sutherland's work is that a scholar needed to proclaim that crimes of the "upper socioeconomic class" were in fact crimes that should be prosecuted. It is apparent that prior to the coining of the term "white collar crime", wealth and power allowed some persons to escape criminal liability.

Pickett and Pickett (2002) use the terms financial crime, white-collar crime, and fraud interchangeably. They define white-collar crime as the use of deception for illegal gain, normally involving breach of trust, with some concealment of the true nature of the activities. White-collar crime is often defined as crime against property, involving the unlawful conversion of property belonging to another to one's own personal use and benefit. Financial 
crime is a profit-driven crime to gain access to and control over money, goods or other property that belonged to someone else.

Bucy et al. (2008) argue that white-collar crime refers to non-violent, business-related violations of state and/or federal criminal statutes, and they make a distinction between "leaders" and "followers" in white-collar crime.

White-collar crime can be defined in terms of the offense, the offender or both. If white-collar crime is defined in terms of the offense, it means crime against property for personal or organizational gain. It is a property crime committed by non-physical means and by concealment or deception (Benson and Simpson, 2009). If white-collar crime is defined in terms of the offender, it means crime committed by higher class members of society for personal or organizational gain. They are individuals who are wealthy, highly educated, and socially connected, and they are typically employed by and in legitimate organizations (Hansen, 2009).

One of the most famous white-collar criminals was Bernhard Ebbers, chief executive officer of WorldCom (Wagner, 2011: 978):

To answer why Bernard Ebbers did this, one must take a look at his personal finances. Bernard Ebbers was extremely wealthy by the time WorldCom began to experience difficulties in 2000. Unfortunately for Ebbers (and ultimately for WorldCom shareholders), his desires exceeded his income. Ebber's purchases included an enormous ranch, timber lands, and a yacht-building company, and his loans totaled over $\$ 400$ million. To secure these loans, he used millions of shares of WorldCom stock as collateral. Any time the price of WorldCom stock went down he needed more cash or assets to maintain his collateral. At one of WorldCom's financial meetings, Ebbers told his employees that his 'lifeblood was in the stock of the company' and that if the price fell below approximately $\$ 12$ per share, he would be wiped out financially by margin calls. Bernard Ebbers could not allow WorldCom's stock price to fall even if it was realistically inevitable that this would eventually occur. As Judge Winter stated, "[t]he methods used were specifically intended to create a false picture of profitability even for professional analysts that, in Ebber's case, was motivated by his personal financial circumstances."

A study in the USA concluded that two main, differentiating, characteristics of whitecollar criminals are irresponsibility and antisocial behavior as compared to other white-collar individuals. The study by Collins and Schmidt (1993) examined the construct validity of personality scales, a personality-based integrity test, and homogenous bio data scales as reflected in their ability to discriminate white-collar criminals from other white-collar employees. A bio data scale is a systematic method of scaling life history experiences. The sample included 365 prison inmates incarcerated in 23 federal correctional institutions for white-collar offenses, and 344 individuals employed in upper-level positions of authority.

\section{FINANCIAL CRIME CATEGORIES}

A number of illegal activities can occur in both the commercial and public sectors. As long as there are weaknesses that can be exploited for gain, advantage will be taken of companies and other organizations as well as private individuals (Pickett and Pickett, 2002).

Therefore, we find a great variety of criminal activities that are classified as financial crime. Figure 1 presents main categories as well as sub-categories of financial crime. The 
four main categories are labeled corruption, fraud, theft, and manipulation, respectively. Within each main category there exist a number of sub-categories.

Fraud can be defined as intentional perversion of truth for the purpose of inducing another in reliance upon it to part with some valuable thing belonging to him or to surrender a legal right (Henning, 2009). Fraud is the unlawful and intentional making of a misrepresentation, which causes actual prejudice or which is potentially prejudicial to another.

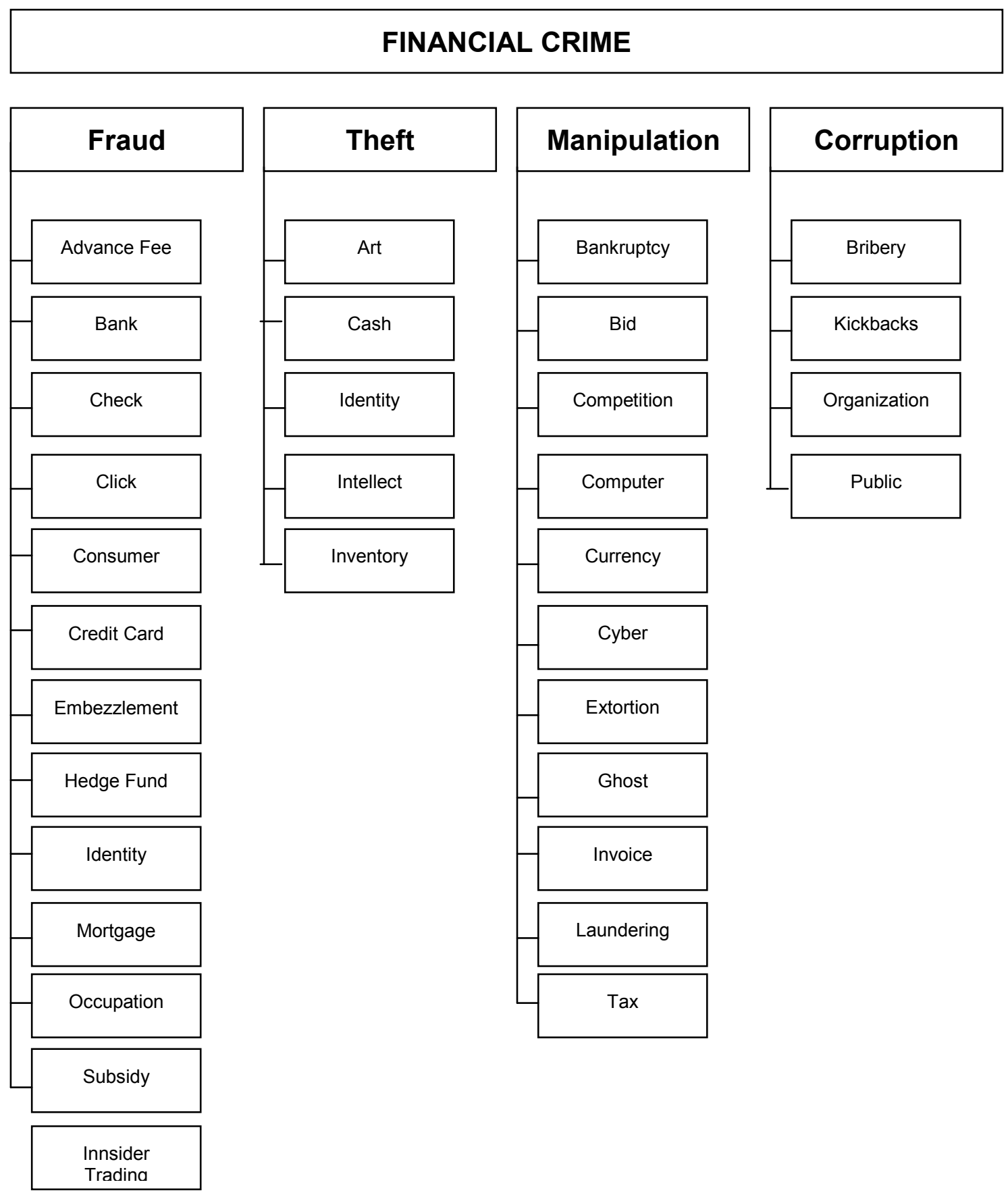

Figure 1. Main categories and sub categories of financial crime. 
Theft can be defined as the illegal taking of another person's, group's or organization's property without victim's consent (Hill, 2008). For example, identity theft combined with identity fraud is the unlawful use of another's personal identifying information. It involves financial or other personal information stolen with the intent of establishing another person's identity as the thief's own. It occurs when someone uses personally identifying information, like name, social security number, date of birth, government passport number, or credit card number without the owners' permission, to commit fraud or other crimes (Higgins et al., 2008). Manipulation can be defined as a means of gaining illegal control or influence over others' activities, means and results such as tax evasion (Malkawi and Haloush, 2008). For example, the failure to comply with national income tax laws is one of the most prevalent financial crimes in many countries.

The Internal Revenue Service in the USA estimated that 245 billion dollars represents the total individual tax gap in the nation (Cecil et al., 2009). Corruption can be defined as the giving, requesting, receiving or accepting of an improper advantage related to a position, office or assignment (Kayrak, 2008). The improper advantage does not have to be connected to a specific action or to not-doing this action. It will be sufficient if the advantage can be linked to a person's position, office or assignment (Økokrim, 2008). An individual or group is guilty of corruption if they accept money or money's worth for doing something that he is under a duty to do anyway, that he is under a duty not to do, or to exercise a legitimate discretion for improper reason (Ksenia, 2008). Corruption is to destroy or pervert the integrity or fidelity of a person in his discharge of duty, to induce to act dishonestly or unfaithfully, to make venal, and to bribe.

\section{RESEARCH METHOD}

Several options exist to identify a substantial sample of white-collar criminals and to collect relevant information about each criminal. However, in a small country like Norway with a population of only five million people, there are limits to available sample size. One available option would be to study court cases involving white-collar crimes and criminals. A challenge here would be to identify the relevant laws and sentences that cover our definition not only of white-collar crime, but also the required characteristics of white-collar criminals.

Another available option is to study newspaper articles, where the journalists already have conducted some kind of selection of higher class, white-collar individuals convicted in court because of financial crime. An advantage of this approach is that the cases are generally publicly known, which makes it easier to identify cases by individual white-collar names. The selective and otherwise filtered information in newspapers might be a problem in other kinds of studies, but is considered an advantage in this study, because white-collar criminals tend to be prominent persons known already from the media. Therefore, the latter option was chosen in this research.

Based on this decision, our sample has the following characteristics as applied by newspapers when presenting news: famous individuals, famous companies, surprising stories, important events, substantial consequences, matters of principles and significant public interest. The sample consists of high profile and large yield offenses. This is in line with research by Schnatterly (2003) who searched the Wall Street Journal for several years in her study of white-collar crime which was published in the Strategic Management Journal.

It must be noted that journalists in Norway enjoy respectability because of their integrity and seriousness. There are very few newspapers engaged in reporting undocumented sensational 
stories. As a result, no such paper has been found in Norway in our area of research into financial crime by white-collar criminals. Some journalists in the financial press have developed sophisticated skills in digging for criminal cases, where they apply robust and transparent methodologies. Every year in Norway, a prestigious prize, the SKUP award, is given to journalist(s) who has (have) conducted an investigation and reported news in a professional way. The prize is awarded by the Norwegian Foundation for a Free and Investigative Press to someone who both found and reported a good story in a respectable and professional way.

\section{CRIMINAL CHARACTERISTICS}

Criminal characteristics collected for each person included gender, age when convicted, age when committing crime, number of years in prison, court level, amount of money involved in the crime, number of persons involved in the crime, crime type, position level, personal income, personal tax, personal wealth according to their income statement, organization revenue, organization employees, private versus public sector, internal versus external detection, source of detection, corporate versus occupational crime, and leader versus follower.

Most white-collar criminals are men. This is confirmed in the sample of 323 persons, which included only 27 female criminals and 296 male criminals. Thus, only 8 percent of the white-collar crime people identified in newspaper articles were women - sometimes labeled pink-collar criminals.

The youngest white-collar criminal in Norway was 17 years old and the oldest was 77 years. A distinction is made between age when convicted and age when committing the crime. On average, a person was convicted 5 years after the crime; thus the average age when committing a crime is 43 years old and the average age when convicted is 48 years old.

Most anecdotal cases, such as Rajaratman, Schilling and Madoff in the USA, were men prosecuted in their 50's or older. This is confirmed in our sample where the average age is 48 years old when convicted in court. These average numbers are similar to a study by Blickle et al. (2006) of 76 convicted German white-collar criminals. In their responding sample, there were 6 female criminals and 70 male criminals. The mean age of the offenders in Germany was 47 years. In a study reported by Benson and Simpson (2009) in the USA, the average age of common criminals was 30 years, while the average age for white-collar criminals was 40 years. It is unclear whether the age of 40 years can be compared to the age of 48 years when convicted, or to the age of 43 years when committing the crime in Norway.

The average jail sentence for 323 convicted white-collar criminals in Norwegian courts was 2.2 years, with a maximum of 9 years and a minimum of 15 days. The longest jail sentence of 9 years was given to a person involved in bank fraud, where the equivalent of 200 million US dollars were involved, before the company went bankrupt. All persons in the sample received a jail sentence for white-collar crime. Compared to the famous US cases mentioned above, such as Rajatmaran, Schilling and Madoff, these sentences are quite modest. However, in a Norwegian context these jail sentences are quite substantial, only surpassed by sentences for organized crime and murder. Also, when comparing to the sample used by Blickle et al. (2006) of white-collar criminals in Germany, there is no substantial difference, since the average was 3.9 years imprisonment in Germany in their sample of 76 convicts. In a US study of several thousand white-collar crime cases, the average prison sentence was only 11 months (Schanzenbach and Yaeger, 2006). 


\section{RESEARCH RESULTS}

Out of 323 convicted white-collar criminals, 161 criminals were convicted of fraud, 21 of theft, 83 of manipulation, and 58 of corruption. As listed in Table 1, criminals can be compared in terms of averages for age, prison, amount, people involved, income and employees. There are no significant differences in the age of criminals. The large majority were around fifty years old when convicted in court. In terms of prison sentences, criminals convicted of fraud received a significantly longer imprisonment sentence when compared to criminals convicted of corruption. This might partly be explained by the next item, which is the amount of the crime. The crime amount influences the court sentence, and the crime amount is usually larger for 'fraud' criminals than for 'corruption' criminals. Crime amount is the magnitude of money in terms of Norwegian kroner that was taken by the criminal. Six Norwegian kroner are equivalent to one US dollar, so a fraud of 54 million Norwegian kroner is approximately equal to 9 million US dollars.

There are some differences in the number of involved persons depending on the crime category. On average, most people are involved in fraud crime cases, while the least people are involved in manipulation crime cases.

All Norwegians are registered with a taxable income every year. All white-collar criminals in our sample had an average income of 345,000 Norwegian kroner (about 60,000 US dollars) in 2009. There is a significant difference between theft criminals and corruption criminals; the former have the lowest income and the latter have the highest income. This is logical since theft criminals enrich themselves, while corruption criminals enrich others for potential benefits in the future.

Table 1. Characteristics of white-collar criminals involved in different kinds of financial crime (*means statistically significant different value).

\begin{tabular}{|c|c|c|c|c|c|}
\hline & $\begin{array}{c}\text { Fraud } \\
161\end{array}$ & $\begin{array}{c}\text { Theft } \\
21\end{array}$ & $\begin{array}{c}\text { Manipulation } \\
83\end{array}$ & $\begin{array}{c}\text { Corruption } \\
58\end{array}$ & $\begin{array}{c}\text { Total } \\
323\end{array}$ \\
\hline $\begin{array}{c}\text { Age } \\
\text { (years) }\end{array}$ & 47 & 44 & 49 & 50 & 48 \\
\hline $\begin{array}{c}\text { Prison term } \\
\text { (years) }\end{array}$ & $2.5^{*}$ & 1.8 & 2.1 & $1.7^{*}$ & 2.2 \\
\hline $\begin{array}{c}\text { Amount } \\
\text { (M kroner) }\end{array}$ & 54 & 10 & 67 & 5 & 46 \\
\hline $\begin{array}{c}\text { Involved } \\
\text { (persons) }\end{array}$ & $4.6^{*}$ & 4.3 & $2.7^{*}$ & 3.4 & 3.9 \\
\hline $\begin{array}{c}\text { Income } \\
\text { (kroner) }\end{array}$ & 243,000 & $227,000^{*}$ & 462,000 & $504,000^{*}$ & 345,000 \\
\hline $\begin{array}{c}\text { Employees } \\
\text { (persons) }\end{array}$ & 113 & 165 & 87 & 162 & 119 \\
\hline
\end{tabular}




\section{DISCUSSION}

We defined the four main financial crime categories by white-collar offenders: fraud, theft, manipulation, and corruption previously in the Financial Crime Categories Section. Most criminals in our sample were convicted of fraud, typically bank fraud. Many were also convicted of manipulation, typically income tax misrepresentation.

Average jail sentences in Norway ranged from 2.5 years to 1.5 years compared to 3.92 years in a study in Germany (Blickle et al., 2006). In comparison, white-collar offenders in the United States have faced sentences far beyond those imposed in prior years. For example, Bernard Ebbers, former CEO of WorldCom, was sentenced to twenty-five years; Jeffrey Skilling, former CEO of Enron, was sentenced to twenty-four years and four months; and Adelphia founder John Rigas received a sentence of fifteen years, with his son Timothy Rigas, the CFO of the company, receiving a twenty-year sentence. Podgor (2007) argues that these greatly increased sentences result in part from the employment of the United States sentencing guidelines structure, which includes in the computation of time the amount of fraud loss suffered. Although the sentencing guidelines have some flexibility resulting from the recent Supreme Court decision in the United States $v$. Booker, the culture of mandated guidelines still permeates the structure and, as such, is prominently followed by the judiciary. Equally influential in these sentences is the fact that because parole no longer exists in the federal system, the time given to these individuals will probably be close to the sentence that they will actually serve.

Despite relatively short jail sentences in Norway, white-collar crime cases are taken serious by the court system as well as the prison service. Also, the public generally doesn't accept excuses for these crimes. When released from prison, very few of the convicted white collar criminals are able to regain their positions in society in terms of prestige, network and financial freedom. When asked what they found to be the worst consequence of their conviction considering media attention, imprisonment years, family collapse, loss of prestige, or financial ruin, answers differ. Many seem to apply techniques based on neutralization theory (Siponen and Vance, 2010). For example, they deny responsibility for the crime, or they find it strange that their actions are illegal, i.e. there is something wrong with the law.

Several avenues for future research are immediately suggested. Theoretical, methodological and policy issues could be expanded. Improvements in theoretical issues as well as what the approach and findings mean for theory and policy might provide an interesting perspective based on the mainly descriptive study presented in this paper.

White collar crimes are committed by people at all levels of the social structure - all they need is the opportunity and mind set. Looking at only those reported in the newspapers, the high visibility white collar crimes certainly bias the results towards people at the higher social level.

\section{CONCLUSION}

Some empirical differences exist in crime categories by white-collar criminals. Fraud, the most frequently tried and convicted crime in court is also associated with the most severe jail sentences. Theft is generally committed by individuals with a lower personal income than other white collar criminals. More criminals participate in fraud crimes than in manipulation crimes. 


\section{Brief biographies}

Petter Gottschalk is professor of information systems and knowledge management in the Department of Leadership and Organizational Management at BI Norwegian Business School. Dr. Gottschalk has published several books and research articles on crime and policing.

\section{References}

[1] Benson M. L., Simpson S. S. (2009), White-Collar Crime: An Opportunity Perspective, Criminology and Justice Series, Routledge, NY: New York.

[2] Blickle G., Schlegel A., Fassbender P., Klein U., Psychology: An International Review 55(2) (2006) 220-233.

[3] Brightman H. J. (2009), Today's White-Collar Crime: Legal, Investigative, and Theoretical Perspectives, Routledge, Taylor \& Francis Group, NY: New York.

[4] Bucy P. H., Formby E. P., Raspanti M. S., Rooney K. E., St. John's Law Review 82 (2008) 401-571.

[5] Cecil H. W., Placid R. L., Pacini C., Journal of Financial Crime, 16(1) (2009) 97-106.

[6] Collins J. M., Schmidt F. L., Personnel Psychology 46 (1993) 295-311.

[7] Collins J. D., Uhlenbruck K., Rodriguez P., Journal of Business Ethics 87 (2009) 89-108.

[8] Gottschalk P., Glasø L., International Letters of Social and Humanistic Sciences 4 (2013) 22-34.

[9] Hansen L. L., Journal of Financial Crime 16(1) (2009) 28-40.

[10] Henning J., Journal of Financial Crime 16(4) (2009) 295-304.

[11] Higgins E. T., American Psychologist 52 (1997) 1280-1300.

[12] Higgins G. E., Hughes T., Ricketts M. L., Wolfe S. E., Journal of Financial Crime 15(3) (2008) 295-307.

[13] Hill C., Journal of Financial Crime 15(4) (2008) 444-448.

[14] Kayrak M., Journal of Financial Crime 15(1) (2008) 60-70.

[15] Ksenia G., Journal of Financial Crime 15(2) (2008) 223-233.

[16] Malkawi B. H., Haloush H. A., Journal of Financial Crime 15(3) (2008) 282-294.

[17] Pickett K. H. S., Pickett J. M., (2002). Financial Crime Investigation and Control. New York: John Wiley \& Sons.

[18] Podgor E. S., Journal of Criminal Law and Criminology 97(3) (2007) 1-10.

[19] Schanzenbach M., Yeager M. L., Journal of Criminal Law and Criminology 96(2) (2006) 757-793.

[20] Schnatterly K., Strategic Management Journal 24 (2003) 587-614.

[21] Simpson S. S., Weisburd D., editors (2009). The Criminology of White-Collar Crime, Springer, New York. 
[22] Siponen M., Vance A., MIS Quarterly 34(3) (2010) 487-502.

[23] Sutherland E. H., (1949). White collar crime, New York: Holt Rinehart and Winston.

[24] Wagner R. E., University of Cincinnati Law Review 79 (2011) 973-993.

[25] Økokrim (2008). Annual Report 2007, Norwegian National Authority for Investigation and Prosecution of Economic and Environmental Crime, Oslo, Norway.

( Received 20 May 2013; accepted 22 May 2013 ) 